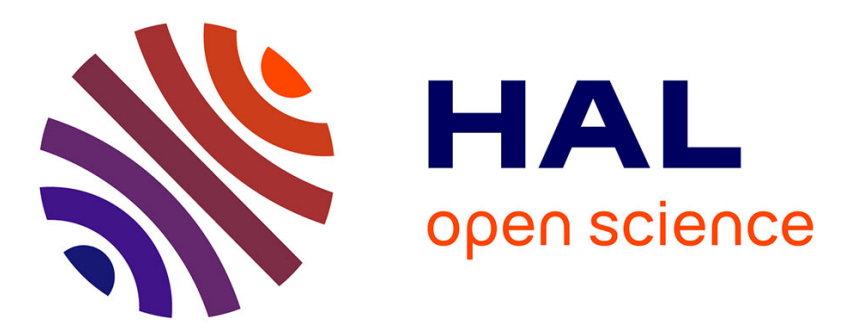

\title{
Actual reproductive conflict during emergency queen rearing in Apis florea
}

\author{
Piyamas Nanork, Petah Low, Kirstin Proft, Julianne Lim, Sureerat \\ Deowanish, Siriwat Wongsiri, Benjamin Oldroyd
}

\section{To cite this version:}

Piyamas Nanork, Petah Low, Kirstin Proft, Julianne Lim, Sureerat Deowanish, et al.. Actual reproductive conflict during emergency queen rearing in Apis florea. Apidologie, 2011, 42 (2), pp.206-210. 10.1051/apido/2010052 . hal-01003587

\section{HAL Id: hal-01003587 \\ https://hal.science/hal-01003587}

Submitted on 1 Jan 2011

HAL is a multi-disciplinary open access archive for the deposit and dissemination of scientific research documents, whether they are published or not. The documents may come from teaching and research institutions in France or abroad, or from public or private research centers.
L'archive ouverte pluridisciplinaire HAL, est destinée au dépôt et à la diffusion de documents scientifiques de niveau recherche, publiés ou non, émanant des établissements d'enseignement et de recherche français ou étrangers, des laboratoires publics ou privés. 


\title{
Actual reproductive conflict during emergency queen rearing in Apis florea*
}

\author{
Piyamas NANORK ${ }^{1}$, Petah A. Low ${ }^{2}$, Kirstin M. ProfT ${ }^{2}$, Julianne LIM ${ }^{2}$, \\ Sureerat DEOWANISH ${ }^{3}$, Siriwat WONGSIRI ${ }^{4}$, Benjamin P. OLDROYD ${ }^{2}$ \\ ${ }^{1}$ Department of Biology, Faculty of Science, Mahasarakham University, Mahasarakham 44150, Thailand \\ ${ }^{2}$ Behaviour and Genetics of Social Insects Lab, School of Biological Sciences A12, University of Sydney, \\ NSW 2006, Australia \\ ${ }^{3}$ Center of Excellence in Entomology: Bee Biology, Biodiversity of Insects and Mites, Department of Biology, \\ Faculty of Science, Chulalongkorn University, Bangkok 10330, Thailand \\ ${ }^{4}$ School of Science, Mae Fah Luang University, Chiang Rai 57100, Thailand
}

Received 9 December 2009 - Revised 5 April 2010 - Accepted 12 April 2010

\begin{abstract}
Unequal relatedness among workers in polyandrous honey bee colonies provides the potential for reproductive conflict during emergency queen rearing. Adult workers can increase their inclusive fitness by selectively rearing their full-sisters as queens. We investigated the paternity of emergency queens in two colonies of Apis florea using five microsatellite loci. In colony 1 there was no significant difference between the proportions of queens and workers in each patriline $(P=0.48)$. In contrast, the relative frequency of patrilines in colony 2 differed significantly between queens and workers $(P=0.03)$. More than a quarter of the queens reared in this colony were of a single patriline, suggesting that larvae were selected for rearing as queens non-randomly.
\end{abstract}

Apis florea / nepotism / emergency queen rearing / DNA microsatellites

\section{INTRODUCTION}

A dwarf red honey bee (Apis florea) queen typically mates with 13 or more drones (Palmer and Oldroyd, 2001). This means that colonies comprise multiple patrilines of supersisters (Seeley, 1985; Oldroyd and Wongsiri, 2006). As a consequence of the non-clonal nature of colonies, there is the potential for reproductive conflict between workers of different patrilines and, under certain circumstances, it is expected that this could translate into actual conflict (Visscher, 1993; Beekman and Ratnieks, 2003). For example, during emergency queen rearing workers could potentially increase their inclusive fitness by nepo-

Corresponding author: Ben Oldroyd, boldroyd@bio.usyd.edu.au

* Manuscript editor: Klaus Hartfelder tistically raising supersister queens (Hamilton, 1964; Ratnieks et al., 2006).

There is mixed evidence for the presence or absence of actual conflict during queen rearing in Apis species as evidenced by some patrilines being over-represented in queen brood. An early study based on allozymes that strongly suggested nepotism in queen rearing (Page et al., 1989), was later criticised on statistical grounds (Oldroyd et al., 1990). More recently three microsatellite studies showed small but statistically significant biases in patriline frequency in queen brood versus worker brood in A. mellifera (Tilley and Oldroyd, 1997; Osborne and Oldroyd, 1999; Châline et al., 2003). However studies of the behaviour of nurse workers on queen cells failed to show that workers direct care towards supersisters (Châline et al., 2005; Koyama et al., 2007). 
The only study of nepotism in A. cerana failed to find significant differences in patriline frequencies between queen and worker brood (Koyama et al., 2009). Here we investigate the possibility of actual reproductive conflict during emergency queen rearing in A. florea, one of the two most basal species of the genus.

\section{MATERIALS AND METHODS}

\subsection{Sample collection}

In June 2008 two wild A. florea colonies were translocated (Oldroyd et al., 2008) to a coconut plantation in Ratchaburi Province, Thailand where they were attached to low tree branches $10 \mathrm{~m}$ apart. Loss of adult bees from the colonies during transfer was minimal. After the colonies had settled down for a week a random sample of workers was taken from each colony by scraping workers from the comb into an open vial of alcohol. The queens were then searched for and transferred into cages. The queens were maintained in cages with attendant workers from their own colonies. Queen removal triggered an emergency queen rearing response, where workers select a portion of the available worker brood to rear as queens (Châline et al., 2003). The colonies were kept queenless until they produced sealed queen cells. We then removed queen larvae and pupae and stored them at $-20{ }^{\circ} \mathrm{C}$ for DNA analysis. We then reintroduced the queens to their respective colonies where they again laid eggs. We successfully repeated the procedure twice for colony 1 and once for colony 2 . Both colonies absconded before the next sample could be taken.

\subsection{Genetic and statistical analysis}

DNA was extracted using Chelex ${ }^{\circledR} 100$ resin (Walsh et al., 1991; Oldroyd et al., 1997). Five microsatellite markers B124, A8, A88, A107 (Estoup et al., 1993, 1994) and Ap24 (Solignac et al., 2003) were amplified using standard PCR methods to determine patrilines of the queens and workers (Estoup et al., 1994; Oldroyd et al., 1996; Palmer and Oldroyd, 2001). The proportion of workers and queen pupae belonging to each patriline in the pooled samples were compared with a resampling version of Fisher's Exact test using the program 'Monte Carlo RxC 2.2' (W. Engels, University of Wisconsin).

\section{RESULTS}

We found 15 patrilines amongst the sample of workers and queens from colony 1 and 22 in colony 2 . The effective paternity of colony 1 , calculated using the correction for sample size proposed by Nielsen et al. (2003), was 9.18, and relatedness within the brood (Pamilo, 1993) was 0.30. Colony 2 had an effective paternity of 11.80 and relatedness of 0.29 . The probability of not detecting a patriline due to two drones having the same alleles at all loci tested was very low $(0.003$ for colony 1 , and 0.0008 for colony 2 ), when calculated using the very conservative assumptions that the only alleles present were those detected in our samples, and that all alleles had equal frequencies (Higgs et al., 2009). In colony 1 there was no significant difference between the proportions of queens $(\mathrm{n}=22)$ and workers $(\mathrm{n}=63)$ in each patriline $(P=$ 0.479 ). In contrast, the relative frequency of patrilines in colony 2 differed significantly between queens $(\mathrm{n}=20)$ and workers $(\mathrm{n}=69$; $P=0.031$ ). More than a quarter of the queens reared in this colony were of a single patriline (Fig. 1), suggesting that larvae of this patriline were selected non-randomly to be raised as queens.

\section{DISCUSSION}

As with some previous studies in A. mellifera (Tilley and Oldroyd, 1997; Osborne and Oldroyd, 1999; Châline et al., 2003), the selection of $A$. florea larvae for rearing as queen cells is not always random with respect to patriline. Three mechanisms have been suggested to explain why certain patrilines can be over-represented in emergency queen cells (Page et al., 1989; Tilley and Oldroyd, 1997): (1) the most numerous worker patriline dominates the process of queen rearing and preferentially rears supersisters; (2) certain patrilines produce workers that are behaviourally, although not necessarily numerically, dominant during queen rearing and preferentially rear their supersisters; or (3) larvae from certain patrilines are particularly attractive to the worker bees for rearing as queens. Which hypothesis is the more likely? 


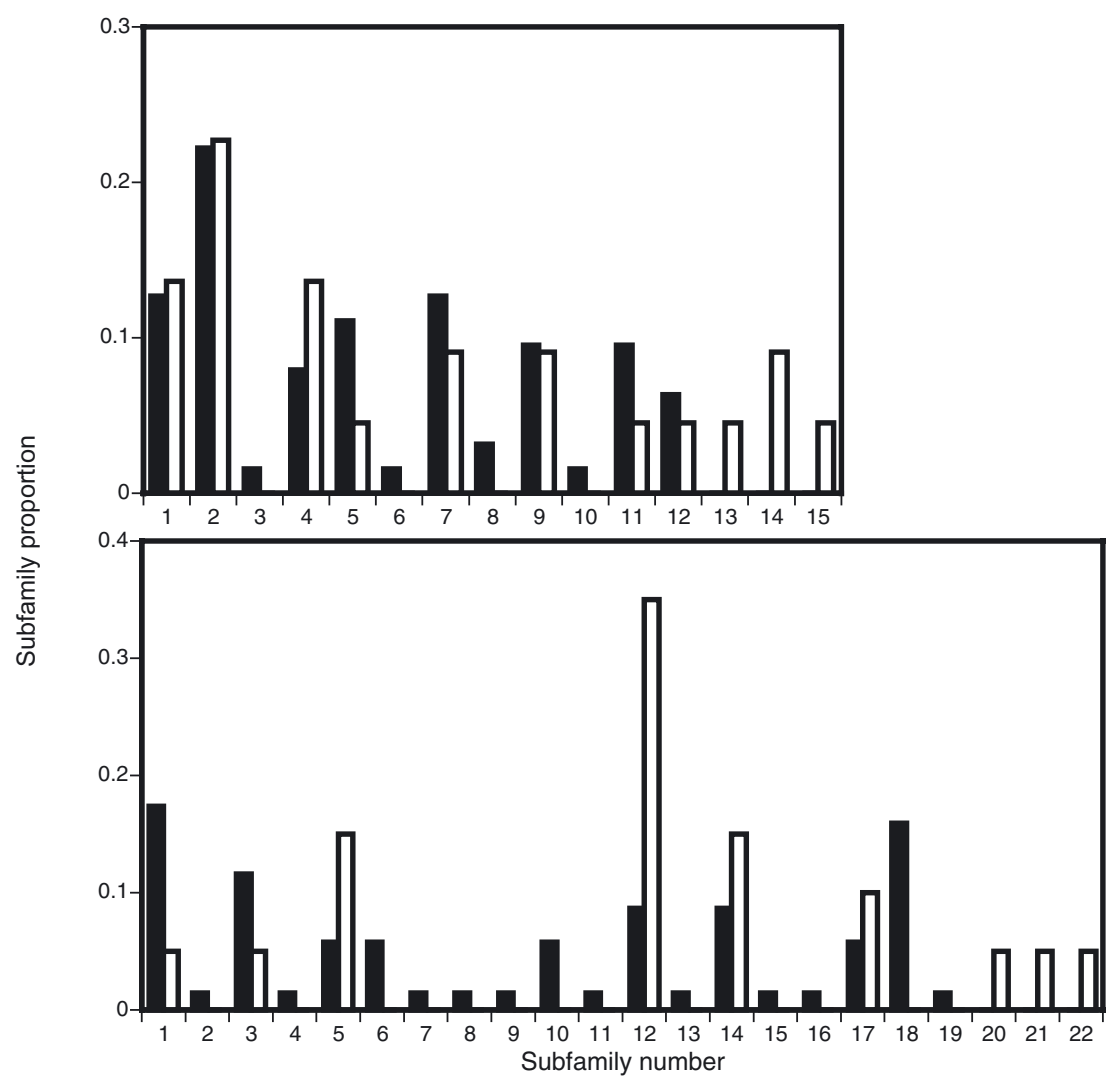

Figure 1. Relative proportions of patrilines amongst workers ( $\square$ white bars) and queen pupae ( $\square$ grey bars) in two colonies of Apis florea undertaking emergency queen rearing. (a) = Colony $1, n=63$ workers, 22 queens; (b) = Colony 2, $n=69$ workers, 20 queens. Patriline frequencies differed significantly between queen pupae and workers in colony $2(P=0.031)$ but not in colony $1(P=0.479)$.

Our data do not support the first hypothesis, which requires that the most commonly reared queens be from the most common worker patriline; in colony 2 , the most commonly reared patriline amongst the queen pupae was not the most numerous among the workers (Fig. 1b). The second and third hypotheses are both supported by our data. In particular, the strong over-representation of patriline 12 in the queens of colony 2 suggests that this patriline was highly attractive to nurse workers for rearing as queens. Such reproductive cheating is known from the leaf cutting ant Acromyrmex echinatior (Hughes and Boomsma, 2008). However, Osborne and Oldroyd (1999) failed to find evidence for cheating genotypes in A. mellifera, since sig- nificant differences in the relative frequencies of patrilines between queen and worker brood were only found in colonies in which brood and workers were related. Châline et al. (2005) were unable to establish a link between the paternity of workers performing queen cell care and the paternity of the queens within the queen cells, also in A. mellifera. Thus the mechanisms that give rise to patriline differences between queen and worker brood remain obscure in A. mellifera and by corollary in A. florea.

The mixed evidence for nepotism during emergency queen rearing that is reported here and elsewhere suggests that in many cases potential conflict does not translate into actual conflict. A variety of mechanisms may select 
against actual conflict in the form of nepotistic behaviour and may explain why, despite expectations arising from kin selection theory, an allele conferring nepotistic behaviour does not rapidly spread to fixation (Ratnieks and Reeve, 1991; Osborne and Oldroyd, 1999). It is possible that informational constraints, leading to high error rates in workers distinguishing between full and half-sisters, reduce the selective pressure for nepotism (Ratnieks and Reeve, 1991). Alternatively, nepotism could have high costs to colony fitness, through the loss of preexisting queen larvae or reduced efficiency of nepotistic workers (Ratnieks and Reeve, 1991, 1992). In this case, selection at the colony level for cooperation and efficiency is likely to predominate over individual-level selection for self interest (Tarpy et al., 2004). Our study suggests that in A. florea, as in other Apis species, actual reproductive conflict may occur during emergency queen rearing, but further work is required to clarify the costs and constraints responsible for regulating its occurrence.

\section{ACKNOWLEDGEMENTS}

This work was supported by the Thailand Research Fund and the Commission on Higher Education (grant number: MRG5080275), the Office of the National Research Council of Thailand and the Australian Research Council. We thank Madeleine Beekman for her helpful comments on the draft.

\section{Existence d'un conflit pour la reproduction du- rant l'élevage des reines de remplacement chez Apis florea.}

Apis florea / népotisme / élevage / reine de remplacement / microsatellites ADN

\footnotetext{
Zusammenfassung - Der Fortpflanzungskonflikt bei der Aufzucht von Ersatzköniginnen bei Apis florea. Ungleichgewichte im Verwandtschaftsgrad von Arbeiterinnen innerhalb eines Volkes bedingt durch Mehrfachpaarung der Königin stellen ein Potential für Fortpflanzungskonflikte bei der Aufzucht von Ersatzköniginnen dar, da Arbeiterinnen durch die Bevorzugung von Vollschwestern bei der Königinnenaufzucht ihre inklusive Fitness erhöhen kön-
}

nen. Anhand von fünf Mikrosatellitenloci untersuchtenwir die Vaterschaft von Ersatzköniginnen bei zwei Völkern der roten Zwergbiene Apis florea. Bei Volk 1 konnten wir keinen signifikanten im Verhältnis von Königinnen zu Arbeiterinnen in Bezug auf die Patrilinien erkennen $(P=0,479)$. Im Gegensatz hierzu waren bei Volk 2 die Unterschiede in den relativen Frequenzen der Patrilinien der Königinnen zu Arbeiterinnen statistisch signifikant $(P=0,031)$. Mehr als ein Viertel der in diesem Volk aufgezogenen Königinnen entstammten einer einzigen Patrilinie (Abb. 1), was auf eine nicht zufallsverteilte Auswahl von Larven für die Ersatzköniginnenaufzucht hinweist.

Die effektive Vaterschaft bei Volk 1 lag bei 9,18 und das Verwandtschaftsverhältnis mit der Brut bei 0,30 . Bei Volk 2 hingegen betrug die effektive Vaterschaft 11,80 und die Verwandtschaft 0,29.

\section{Apis florea / Nepotismus / Ersatzköniginnenauf- zucht / DNA Mikrosatelliten}

\section{REFERENCES}

Beekman M., Ratnieks F.L.W. (2003) Power over reproduction in the social Hymenoptera, Philos. Trans. R. Soc. Lond. B. 358, 1741-1753.

Châline N., Arnold G., Papin C., Ratnieks F.L.W. (2003) Patriline differences in emergency queen rearing in the honey bee Apis mellifera, Insectes Soc. 50, 234-236.

Châline N., Martin S.J., Ratnieks F.L.W. (2005) Absence of nepotism towards imprisoned young queens during swarming of the honey bee, Behav. Ecol. 16, 403-409.

Estoup A., Solignac M., Cornuet J.-M. (1994) Precise assessment of the number of patrilines and of genetic relatedness in honey bee colonies, Proc. R. Soc. Lond. B 258, 1-7.

Estoup A., Solignac M., Harry M., Cornuet J.-M. (1993) Characterization of (GT)n and (CT)n microsatellites in two insect species: Apis mellifera and Bombus terrestris, Nucleic Acids Res. 21, 1427-1431.

Hamilton W.D. (1964) The genetical evolution of social behaviour. I \& II, J. Theor. Biol. 7, 1-52.

Higgs J.S., Wattanachaiyingcharoen W., Oldroyd B.P. (2009) A scientific note on a geneticallydetermined colour morph of the dwarf honey bee, Apis andreniformis (Smith, 1858), Apidologie 40, 513-514.

Hughes W.O.H., Boomsma J.J. (2008) Genetic royal cheats in leaf-cutting ant societies, Proc. Nat. Acad. Sci. USA 105, 5150-5153.

Koyama S., Harano K.-i., Hiroto T., Satoh T., Obara Y. (2007) Rearing of candidate queens by honeybee, Apis mellifera, workers (Hymenoptera: 
Apidae) is independent of genetic relatedness, Appl. Entomol. Zool. 42, 541-547.

Koyama S., Takagi T., Martin S.J., Yoshida T., Takahashi J. (2009) Absence of reproductive conflict during queen rearing in Apis cerana, Insectes Soc. 56, 171-175.

Nielsen R., Tarpy D.R., Reeve H.K. (2003) Estimating effective paternity number and the effective number of alleles in a population, Mol. Ecol. 12, 31573164.

Oldroyd B.P., Clifton M.J., Wongsiri S., Rinderer T.E., Sylvester H.A., Crozier R.H. (1997) Polyandry in the genus Apis, particularly Apis andreniformis, Behav. Ecol. Sociobiol. 40, 17-26.

Oldroyd B.P., Gloag R.S., Even N., Wattanachaiyingcharoen W., Beekman M. (2008) Nest site selection in the open-nesting honeybee Apis florea, Behav. Ecol. Sociobiol. 62, 1643-1653.

Oldroyd B.P., Rinderer T.E., Buco S.M. (1990) Nepotism in the honey bee, Nature 346, 707-708.

Oldroyd B.P., Smolenski A.J., Cornuet J.-M., Wongsiri S., Estoup A., Rinderer T.E., Crozier R.H. (1996) Levels of polyandry and intracolonial genetic relationships in Apis dorsata (Hymenoptera: Apidae), Ann. Entomol. Soc. Am. 89, 276-283.

Oldroyd B.P., Wongsiri S. (2006) Asian Honey Bees. Biology, Conservation and Human Interactions, Harvard University Press, Cambridge, Ma.

Osborne K.E., Oldroyd B.P. (1999) Possible causes of reproductive dominance during emergency queen rearing by honeybees, Anim. Behav. 58, 267-272.

Page R.E., Robinson G.E., Fondrk M.K. (1989) Genetic specialists, kin recognition and nepotism in honey-bee colonies, Nature 338, 576-579.

Palmer K.A., Oldroyd B.P. (2001) Mating frequency in Apis florea revisited (Hymenoptera: Apidae), Insectes Soc. 48, 40-43.
Pamilo P. (1993) Polyandry and allele frequency differences between the sexes in the ant Formica aquilonia, Heredity 70, 472-480.

Ratnieks F.L.W., Foster K.R., Wenseleers T. (2006) Conflict resolution in insect societies, Annu. Rev. Entomol. 51, 581-608.

Ratnieks F.L.W., Reeve H.K. (1991) The evolution of queen-rearing nepotism in social Hymenoptera: effects of discrimination costs on swarming species, J. Evol. Biol. 4, 93-115.

Ratnieks F.L.W., Reeve H.K. (1992) Conflict in singlequeen Hymenopteran societies: the structure of conflict, and processes that reduce conflict in advanced eusocial species, J. Theor. Biol. 158, 33 65.

Seeley T.D. (1985) Honeybee ecology, Princeton University Press, Princeton.

Solignac M., Vautrin D., Loiseau A., Mougel F., Baudry E., Estoup A., Garnery L., Haberl M., Cornuet J.-M. (2003) Five hundred and fifty microsatellite markers for the study of the honeybee (Apis mellifera L.) genome, Mol. Ecol. Notes 3, 307-311.

Tarpy D.R., Gilley D.C., Seeley T.D. (2004) Levels of selection in a social insect: a review of conflict and cooperation during honey bee (Apis mellifera) queen replacement, Behav. Ecol. Sociobiol. 55, 213-523.

Tilley C.A., Oldroyd B.P. (1997) Unequal representation of subfamilies among queen and worker brood of queenless honey bee (Apis mellifera) colonies, Anim. Behav. 54, 1483-1490.

Visscher P.K. (1993) A theoretical analysis of individual interests and intracolony conflict during swarming of honey bee colonies, J. Theor. Biol. $165,191-212$.

Walsh P.S., Metzger D.A., Higuchi R. (1991) Chelex (R)100 as a medium for simple extraction of DNA for PCR-based typing from forensic material, Biotechniques 10, 507. 